\title{
Starting from Scratch: The First Building Tradesmen of Middlesex County By Robert W. Craig
}

DOI: http://dx.doi.org/10.14713/njj.v2i1.25

"Starting from Scratch" examines the earliest years of Middlesex County from the pointof-view of the building tradesmen--the carpenters, bricklayers, and others--who constructed the towns of Woodbridge, Piscataway, and Perth Amboy between the 1660s and the 1680s. It shows that by identifying these men by name it is possible to trace their careers and to reveal a considerable amount of their working lives. That Piscataway, for example, was settled more slowly than Woodbridge is mirrored by the smaller number of building tradesmen there who have been identified. The building tradesmen of Woodbridge and Piscataway tended to acquire property and rise to the social status of yeomen, while many of those in Perth Amboy arrived in the colony as indentured servants and remained property-less even after their time of service ended. In Woodbridge, especially, building tradesmen dominated the town's leadership during the years of Philip Carteret's governorship. And ironically, despite the remarkably rich clay deposits that would later be found in Middlesex County, the towns failed to attract more than a handful of masonry tradesmen, and the local clays went almost completely unexploited in the seventeenth century. Finally, studies that focus on the experiences of representative colonists, such as of building tradesmen, could collectively provide the basis for a new history of colonial New Jersey.

To make New Jersey a fact on the ground in America required the blood, toil, tears, and sweat equity of hundreds of families who became the first group of New Jersey's English colonists. Nothing was already prepared for them when they arrived in the 1660s, but together during the first decade they managed to settle into their first houses, and during the first 
generation they built the environment that would sustain them into the eighteenth century and lead New Jersey in the direction of permanence.

The previous forty years had been characterized by a bewildering array of failed attempts to colonize between the west side of the Hudson River and the Delaware valley. Two things, then, are immediately striking about the period after 1664: all of a sudden, New Englanders planted a successful colony, even though a small one; and New Jersey's historians have taken that remarkable achievement completely for granted, while pursuing a political story that was, at best, a side plot to what was principally going on, which was that the colony grew from a European population of less than one thousand in 1664 to about fifteen thousand by 1700, with all that that implied for its physical and social development. The existing historiography of New Jersey's beginnings is proprietor-centric: it over-emphasizes the governors, their councils, and the proprietors (the uppermost one percent), while generally ignoring the individual and collective accomplishments of the several towns, even though the growth of those achievements would become far more determinative of the colony's future than would its ineffective political leadership. Understanding the colony's building tradesmen provides a path that leads into that story. ${ }^{1}$

The other 99 percent built the colony, with very little help from above. One of the most telling moments in their experience came in 1686 when the East Jersey Assembly refused to

\footnotetext{
${ }^{1}$ The tone and point of view at least with respect to East New Jersey, in which Middlesex County was located, was set in the eighteenth century by James Alexander (Elizabethtown Bill in Chancery, 1747), the Proprietors' agent, and was reinforced in the nineteenth century by William A. Whitehead (East Jersey under the Proprietary Governments, 1846), who had married into the Parker family in Perth Amboy, a leading family among the Proprietors. In the twentieth century, Richard P. McCormick (New Jersey from Colony to State, 1964) was himself a member of the General Board of the East New Jersey Proprietors. Most recently, Maxine Lurie's treatment of this period strives for more balance, but still places the political story at the center of the narrative. See Maxine N. Lurie and Richard F. Veit eds., New Jersey: A History of the Garden State (Rutgers University Press, 2012). The principal exception to this historiographical tradition has been the work of cultural geographer Peter O. Wacker, whose Land and People: A Cultural Geography of Pre-Industrial New Jersey (New Brunswick, NJ: Rutgers University Press, 1975) has helped to provide a countervailing point-of-view.
} 
enact the revenue measures the proprietors wanted. The Assemblymen pointed out that it was the towns, by taxing their townspeople, that had thus far paid for all of the public improvements. But even that principled stand overlooks a larger issue that historians, too, have ignored: that the 99 percent made the vast majority of the private investment also. The council of West New Jersey alluded to this issue within its own colony when it wrote to the West Jersey proprietors resident in England: "you would please to consider what a great work it is not only to settle, but to raise and erect a province and country from the first foundations out of the woods, and what charges so difficult a work needs..."2

For nearly all that was built in Middlesex County, the seventeenth-century colonists relied first on a group of building tradesmen who accompanied them to New Jersey and then by others who joined them. With the exception of temporary shelters that anyone might build--and fences--the first real houses, and all that came afterward, were built by persons who for their livelihoods practiced one or another of the building trades--mostly carpenters. As Abbott Lowell Cummings observed in his study of how early Massachusetts houses were built, "It is important to realize that we are dealing consistently throughout ... with a professional product. [Even] the very simplest houses were carpenter-built." 3 In his diary from the 1680s, Benjamin Clarke of Piscataway Township in Middlesex County noted that even the smallest building repair project was undertaken only when building tradesmen were on hand to perform it. ${ }^{4}$

We can learn a lot about how the colony grew by focusing on these tradesmen. We can know many of them by name, for they often enough identified the trades they practiced. And

\footnotetext{
${ }^{2}$ Quoted in John E. Pomfret, The Province of West New Jersey (Princeton, NJ: Princeton University Press, 1956): 162.

${ }^{3}$ Abbott Lowell Cummings, The Framed Houses of Massachusetts Bay, 1625-1725 (Cambridge, MA: Belknap Press, 1979): 40.

${ }^{4}$ Robert W. Craig, "Benjamin Clarke, Sr., and His Diary of the Early Raritan Valley," Princeton University Library Chronicle 66, 3 (Spring 2005): 393-438.
} 
knowing their names is important for revealing their working lives. As historian Roger Moss observed more than four decades ago, unfavorable circumstances that surround the study of building tradesmen in the colonial era have strongly tended to "reinforce [a] myth of the anonymous craftsman." This has had profound consequences for architectural history, where an "object-centered approach" based on the careful study of surviving buildings can advance our understanding only so far. These shortcomings, according to Moss, "can only be overcome if the men themselves are identified, without regard for wealth and influence or whether or not examples of their work survive."

From the available evidence, we can sketch a rough outline of the careers of dozens of Middlesex building tradesmen and learn something about how they worked together. This new approach to the study of seventeenth-century New Jersey puts the emphasis in an unexpected place--on the common experiences of representative colonists. In doing so, one calls back into memory an almost entirely unfamiliar cast of characters. It is they, in effect, who housed the entire populace.

Middlesex County is a good place to begin this examination. The survival of early records is better there than in some other parts of the colony. Woodbridge's surviving records date from the end of 1668; Piscataway's and Middlesex County's from 1683. In addition, the nearness of the provincial secretary in Perth Amboy appears to have led to the recording of a higher percentage of land records than in most other parts of the colony. Middlesex also permits attention to be focused on the contrasts between the very different experiences of Woodbridge and Perth Amboy. And Woodbridge, because it came to terms with the East Jersey proprietors over quitrents, would not require digression into the well-rehearsed questions over the

\footnotetext{
${ }^{5}$ Roger W. Moss, "Master Builders: A History of the Colonial Philadelphia Building Trades," Ph.D. dissertation, University of Delaware, 1972. p.4

${ }^{6}$ Ibid., "Master Builders," 6-7.
} 
proprietors' legitimacy to govern that would inevitably occur in any discussion of Elizabethtown, Newark, Middletown, or Shrewsbury, and thus draw attention away from the building tradesmen themselves.

\section{Woodbridge and the First 'Wave' of Construction}

To explain the formation of Middlesex County requires a brief recitation of well-known events. The English takeover of Dutch New Amsterdam in August 1664 installed Richard Nicolls as governor of New York. Within the next few months he took several steps that have been dissected by every historian who has examined this period: approval for New Englanders to settle the first English town west of the Hudson River; acceptance of the resulting Indian purchase; and issuance of the Elizabethtown patent. This patent encompassed nearly all of the present Union County and the entire area of Middlesex north of the Raritan River. New Englanders subsequently bought the right to found two towns between the Raritan and Rahway rivers. These became Woodbridge and Piscataway, settled at first by groups from Massachusetts Bay north of Boston, and from New Hampshire and the Maine border, respectively. To link them together into the county that became Middlesex made evident sense.

The Woodbridge Township families began their settlement along both sides of what was called Pakiack Creek (now Woodbridge Creek), which flowed into the Arthur Kill that separates New Jersey from Staten Island about midway between the Rahway and Raritan rivers. The site of the future Perth Amboy at the mouth of the Raritan--a more likely first place to settle--was left unoccupied. Under the terms that then prevailed, Woodbridge reserved that land for the East Jersey proprietors, who shortly afterward established Perth Amboy to become the provincial capital in 1683. 
The 19th-century historian of Union and Middlesex counties, W. Woodford Clayton, concluded that Daniel Peirce, who hailed from Newbury, Massachusetts, was the de facto leader of the enterprise to establish Woodbridge. ${ }^{7}$ Peirce arrived in the colony in August 1665 with Governor Philip Carteret, and Clayton accordingly concluded that "Woodbridge was settled in the latter part of 1665. The land was ... [made over] to Governor Carteret and John Ogden (himself a stone mason), who in 1666 sold it to Daniel Pierce and eight associates from Newbury, Haverhill, and other places in Massachusetts." 8

Very little building construction took place in Woodbridge during the years 1665-67, before the settlement could begin in earnest. While the legal arrangements for land titles were being worked out with Carteret, his authorization being secured for the founding of the two towns, and the purchase of the Indian title made, were there one or two houses built, perhaps also some temporary shelters? If temporary shelters were built at all in Woodbridge or Piscataway, some of them were likely built during these years. In two passages, the Woodbridge town records use the words "pitch" and "pitched" to denote the first residency on lands before any houses were built, suggesting both the presence of informal occupancies supported by temporary shelters, and that tents may have been the kind used. ${ }^{9}$ In any case, however, such shelters would likely have been limited to ones used by those few among the first associates who were active in completing the initial preparations for the larger, intended number of families to follow. These organizers would have needed to be present for some length of time, for example, to prepare for

\footnotetext{
${ }^{7}$ W. Woodford Clayton, The History of Union and Middlesex Counties, New Jersey... (Philadelphia: J.B. Lippincott Press, 1882): 174, 243.

${ }^{8}$ Ibid., 243. Newbury was (and is) a town in the extreme northeast of Massachusetts just south of the New Hampshire border and near the coast. By the 1660s it had already yielded up other groups of migrants who founded other Massachusetts towns before New Jersey land became available. What is now the separate town of Newburyport was a portion of Newbury in the seventeenth century.

${ }_{9}^{9}$ Woodbridge Town Records, Liber A, 164,167. Division of Special Collections and University Archives, Rutgers University Libraries, New Brunswick, NJ. Hastily built, roofed-over cellars and wigwams that mimicked Native American dwellings evidently were used in some places.
} 
and carry out the surveys for house lots and meadow lots that were first undertaken in Woodbridge in December 1667. There having been such shelters helps explain, at least for Woodbridge, the presence of heads of families who signed oaths of allegiance in the several towns long before their houses could have been completed and even before their individual lands were allocated to them.

The Woodbridge town meeting minutes evidently began with this allocation of house and meadow lots. In what was evidently the first, formal town meeting, Daniel Peirce was elected deputy surveyor for the town, and his son, Joshua Peirce (not a building tradesman) was elected town clerk. A dispute arose the following year, however, which led the townsmen to elect a new clerk. For whatever reason, Peirce, in turn, refused to hand over the records from the town's first year, and the town evidently never collected them. ${ }^{10}$ Joshua Peirce died before the end of 1670. The town records that survive begin with those written by Peirce's successor, and they commence in mid-stream on January 1st, 1668/9, like a book that begins in mid-sentence. Daniel Peirce did not long remain in Woodbridge. In 1669 Carteret confiscated from him a farm he had laid out for himself, and he removed Peirce from his position as deputy surveyor for Woodbridge. Not long after, or perhaps after the death of his son, Peirce returned to Newbury. ${ }^{\mathbf{1 1}}$

It is possible, to a degree, to gauge the buildup of houses in Woodbridge after the granting of the first town lots. In February 1667/8, when an oath of allegiance was administered in Woodbridge, thirteen adult men signed it. ${ }^{12}$ A description of Woodbridge nearly one year later has survived, as a report of the laying out of the first highways on both sides of Pakiack

\footnotetext{
${ }^{10}$ Woodbridge records, Liber A, 158.

${ }^{11}$ Although none of the early Woodbridge houses survive, amazingly, Peirce's own house in Newbury still stands. Built of stone about 1690 after his return from Woodbridge, and known as the Spencer-Peirce-Little house, it is operated as a museum by Historic New England. That house has also been extensively studied by archaeologist Mary C. Beaudry of Boston University.

${ }^{12}$ Wacker, Land and People, 130, states that there were eleven oath takers, but his source, NJA, 1st series, 1:50 shows thirteen names. One of the signers was a John Smith, but it is uncertain whether this was John Smith the millwright, because there were three men of that name in early Woodbridge.
} 
Creek. Pursuant to an order of the town made December 11, 1668, a committee briefly described the roads that they laid out, in the process indicating that at least seven houses already existed. The report also mentioned thirteen other properties as lots with no reference to a house. And of the seven houses, four were identified by the owner's name, and a curious phrase, the "Now Dwelling House" of. ${ }^{13}$ This phrase indicates recent construction or recent occupancy, which in these cases likely amounted to the same thing. So, a year after the first lots were allocated, only seven owners had built on their lands, and, of those houses, four were sufficiently more recent than the others that the scribe felt moved to so indicate.

On June 1, 1669, Governor Carteret issued a corporate charter to the "Township of Woodbridge," formalizing the town's municipal rights and responsibilities. The grateful town "thankfully Excepted [sic]."14 This charter provided an accommodation over quitrents, such that Woodbridge was never troubled in its dealings with the East Jersey Proprietors. Perhaps as a result, one gains a sense in reading the town records that Woodbridge had a relatively smooth build-up during the generation that followed $1667 .{ }^{15}$ The townspeople responded that summer by adding fourteen more heads of families to the ranks of inhabitants and freeholders, bringing them closer to their desired goal of sixty resident families. Each of the fourteen received a house lot, but with the provision that they build a house on it by the next Michaelmas (September 29th).

Several carpenters were among the first arrivals at the newborn Woodbridge village. John Pike Sr., also a Newbury man, another of the organizers of the settlement enterprise, is said

\footnotetext{
13 The cunning similarity in the manuscript between a lower-case "e" and a lower-case "o" means that it might, indeed, have been written as the "New Dwelling House." Woodbridge Town Records collection, folder 3, MG 68, New Jersey Historical Society [NJHS], Newark, NJ.

${ }^{14}$ Woodbridge, Liber A, 162.

${ }^{15}$ Cf. Clayton, 555; John Allen Latschar, "East New Jersey, 1665-1682: Perils of a Proprietary Government," (Ph.D. dissertation, Rutgers University, 1978), 130. Latschar effectively explains the relatively cooperative relationship that Woodbridge had with the provincial government, and the rewards that it reaped as a result--including the charter-which were denied to the other Puritan towns: Newark, Elizabethtown, and Piscataway.
} 
to have been a carpenter, which his son, John, Jr., either already was or later became. Pike was the first among those Woodbridge men who signed the oath of allegiance in February 1667/8. The other carpenters at Woodbridge village who probably built the houses of the first wave were John Bishop, John Dennis, Robert Rogers, Israel Thornell, and John Ilsley, with help from John Smith and perhaps Jonathan Dunham. That Daniel Peirce was also a blacksmith, practitioner of a trade very necessary for housebuilding, suggests that the organizers recognized how crucial the presence of building tradesmen, especially carpenters, would be at the outset. New Englanders embodied a wood-building culture wherein framed houses were the norm, and they brought that predisposition to New Jersey.

John Bishop, Sr. was a carpenter from Newbury, Massachusetts. Although apparently it was his son, John Jr., not himself, who signed the oath of allegiance in February 1667/8, John Sr.'s was one of the first three houses built in Woodbridge, as noted in December $1668 .{ }^{16}$ In September 1669, the town appointed him with two other men to negotiate for the building of a bridge over the Pakiak Creek. ${ }^{17}$ Bishop's house was in the heart of the village, near where the bridge was built, and near where the town set land aside for its meetinghouse and cemetery. Bishop's son Jonathan also appears in the records as a millwright, beginning in $1682 .{ }^{18}$

John Dennis was present as early as 1669 and may have been a close relative of Robert Dennis who acquired property on the east side of Pakiak Creek, possibly as part of the first division in 1667 . He may have been a carpenter in Woodbridge from the beginning, since he was named to a committee in 1670 to help negotiate for the building of the town mill (see

\footnotetext{
${ }^{16}$ NJA, 1st ser., 1:050; Woodbridge Town Records collection, folder 3, MG 68, NJHS.

${ }^{17}$ Woodbridge, Liber A, p.167. RUL.

${ }^{18}$ Dally, 93.
} 
below), but the earliest document that explicitly identifies him as a carpenter is dated $1681 .{ }^{19} \mathrm{He}$ died in 1695 . His son, John, Jr., followed him into the trade, but died young in $1703 .{ }^{20}$

John Ilsley apparently was a young carpenter when he came to Woodbridge. His brother Elisha was one of the Woodbridge men who signed the oath of allegiance in February 1667/8, and he was granted a house lot in July $1669,{ }^{21}$ with the requirement that a house be built on it by the end of September, but he evidently did not remain in Woodbridge. Further checking may reveal whether John instead came to Woodbridge to make good on Elisha's commitment, but in any case by February 1673/4 he was in Woodbridge working as a carpenter when he bought a house lot from fellow carpenter Robert Rogers. ${ }^{22}$ In October 1674 John acquired Elisha's house lot and his meadow, with the help of a third brother, William, who also came to Woodbridge. ${ }^{23}$ When he acquired 99 additional acres from Samuel Moore the same year, he passed the 100-acre threshold that would later be established as a minimum standard for voting. ${ }^{24}$ Although he probably continued as a carpenter, he held sufficient property to be classed as a yeoman, and he ceased identifying himself in public records as a tradesman. In 1679/80 and again in 1681/2, Ilsley was chosen to serve as an assistant in the Woodbridge municipal court. ${ }^{25}$ In December 1695 he was elected to serve as a Woodbridge deputy in the East Jersey assembly. Ilsley epitomized the dominance of building tradesmen within the public life of Woodbridge. The historian John A. Latschar identified thirteen Woodbridge men who "held between them

\footnotetext{
${ }^{19}$ CNJR, 226.

${ }^{20}$ See, for example, Middlesex County Deeds, p.97, Early Middlesex County Records Collection, Special Collections and University Archives, RUL.

${ }^{21}$ NJA, 1st series, 1:50; CNJR, 130; Woodbridge, Liber A, 162.

${ }^{22}$ Ibid., 131.

${ }^{23}$ Ibid., 130.

${ }^{24}$ Ibid., 132.

25 Ibid., 44, 46.
} 
practically all town offices during the period prior to 1682."26 These were also the only Woodbridge men who held provincial offices in those years. Seven of them, a majority, were building tradesmen. Both Pike and Bishop served on the Governor's council.

Israel Thornell ${ }^{27}$ was given a house lot in August 1669 with the provision that he build on it immediately. He added to his holdings in 1676 when he received a patent for 96 acres in Woodbridge, added 60 acres more by purchase in 1683, and another 30 acres in 1686. Woodbridge elected Thornell to be rate-gatherer (tax collector) in 1688, but he took ill that year and died. When he signed his last will and testament in August, fellow carpenter John Pike, Jr., was a witness. ${ }^{28}$ His accounts with the township were left in disarray upon his death, whereupon John Ilsley volunteered to sort them out. ${ }^{29}$

Unlike the other Newbury carpenters whose work lives were unencumbered, Robert Rogers came to Woodbridge as an indentured servant. The need for carpenters was so pressing in August 1669 with so many committed at once to building houses that the Woodbridge town meeting granted him the status of inhabitant and freeholder, even while recognizing his status as a servant, "provided that when his time is out, he Stays in this town and Improves it as others Do." $"$ In a couple of other cases, the town conditioned similar awards on the proviso that the grantee practice his trade in the town. Certainly they must have expected that Rogers would, although the holder of his indenture would have had something to say about it. Rogers remained in Woodbridge until his death in $1686 .^{31}$

\footnotetext{
${ }^{26}$ John Allen Latschar, "East New Jersey, 1665-1682: Perils of a Proprietary Government," (Ph.D. dissertation, Rutgers University, 1978), 130.

${ }^{27}$ The family eventually adopted the spelling "Thornal" but during the 17th century the name was variously spelled. cf. Clayton, 560, 850.

${ }^{28}$ Ibid., 217.

${ }^{29}$ Clayton, 560.

${ }^{30}$ Woodbridge, Liber A, p.163.

${ }^{31}$ CNJR, 124.
} 
The Rahway River was the northern boundary of Woodbridge, dividing it from Elizabethtown, and the south side of it promptly became a secondary area of initial settlement within the township. ${ }^{32}$ Henry Jaques, Sr. was a carpenter from Newbury, where he had been hired in 1661 to build a gallery inside the Newbury meetinghouse. ${ }^{33}$ Together with his son, Henry, Jr., he acquired more than 300 acres on the south side of the Rahway River, abutting the road from Woodbridge to Elizabethtown. ${ }^{34}$ Their patent was issued in March 1670 (new style), but he was present at least from the year before. At Rahway, his neighbor to the west was Hugh March [or Marsh], also a Newbury man. Pomfret identified Marsh as a carpenter, ${ }^{35}$ but the evidence is unclear. Was he confusing Hugh with John Marsh, a Woodbridge sawmill owner in 1683? If Jaques and Marsh were both carpenters on the Woodbridge side of the Rahway River from the first years of the settlement, they likely were responsible for much of the construction there in the first wave, but Henry Jaques, Sr. died in $1679,{ }^{36}$ and by that time Hugh Marsh had returned to Newbury. ${ }^{37}$

Jaques' widow soon afterward married Samuel Moore, one of the town's founding leaders. A telling moment for the Woodbridge building tradesmen came on November 10, 1683 when Moore signed his last will and testament. Among those to witness the signing were the corps of men who had built or were building the town that Moore had fostered: John Pike (carpenter), John Bishop (carpenter), Matthew Moore (carpenter), John Ilsley (carpenter), Israel

\footnotetext{
${ }^{32}$ For the authorization in August 1669 of Woodbridge inhabitants to seek out for settlement other areas within the town bounds than Woodbridge village, see Woodbridge, Liber A, 164.

${ }^{33}$ This is one of the few instances in which research has revealed a specific building project that has been attributed to a New Jersey building tradesman in the place of his former residence.

${ }^{34}$ Clayton, p.244, stated that he was "one of the original nine associates of Woodbridge."

${ }^{35}$ Pomfret, East New Jersey, 039; also Dally, Woodbridge and Vicinity, 20.

${ }^{36}$ CNJR, 044.

${ }^{37}$ Ibid., 043.
} 
Thornell (carpenter), Ezekiel Bloomfield (carpenter), and Jonathan Bishop (sawmill owner). ${ }^{38}$ These men shared much more than just a trade.

\section{The Woodbridge Gristmill}

With carpenters to build the houses, Woodbridge still lacked one vital building that was essential to the well-being of any town: a gristmill. All of the families were clearing land for cultivation of grains, especially wheat, and it was important to have a mill ready to grind that first harvest. On March 1, 1669/70, the town meeting named a committee to "take a View of all the places that there is any Likelyhood of Building a Mill, and give in their Reports [at] the Next towne Meeting." 39 Building a mill was much more ambitious than building houses, and required special skills that most carpenters did not possess. Mills, with their interlocking machinery of wheels, gears, grinders, bolters, and cranes, were usually constructed by a team of two carpenters, at least one of whom was a millwright. On March 18, 1669/70, little more than two weeks following the town meeting, John Smith, the presumptive head of the committee, was awarded a patent from Governor Carteret for 511 acres, the bulk of which was 390 acres west of Hogg Hill. ${ }^{40}$ The document identifies Smith as a millwright, and the only justification for such a transaction would have been to compensate him for the costs and troubles of getting a mill built and operating. But Smith was also leading a faction that opposed the governor over the patenting of Woodbridge lands, and Carteret wrote that Smith "is taxed for a disturber of the public peace of Woodbridge," and he suspended Smith "“from doing anything in the public affairs' of either Woodbridge or the province."41 As with the example of Peirce, this was another instance of Carteret, however justified he felt, taking an action that interfered with the physical

\footnotetext{
${ }^{38}$ Ibid., 121.

${ }^{39}$ Woodbridge, Liber A, 174.

${ }^{40}$ CNJR, 011.

${ }^{41}$ Latschar, 212. Latschar cites East Jersey Deeds, Bk. 3, p.39, for the suspension.
} 
development of the colony he governed. Each time it resulted in a departure from the colony or a pulling back from its public affairs.

Evidently as a result, the town went in another direction. On June 8, 1670, they reached an agreement with Jonathan Dunham, a Massachusetts millwright, to "Come to Woodbridge abovesaid and Bring ... a good pair of Mill Stones ... and Iron work and other things fitting for a mill..." and to build and finish the mill by June $30,1671 .^{42}$ In return, Woodbridge promised to make Dunham an inhabitant and freeholder of the town, "and to have the Same proportion of upland and Meadow, and by the Same Rule that other Inhabitants have theirs." ${ }^{43}$ Woodbridge drove the better bargain. Dunham came to Woodbridge, finished the mill and then operated it for many years, even into the 18th century, becoming a fixture in township affairs and the progenitor of an important New Jersey family. Smith soon departed from Woodbridge, eventually moving to the Plymouth colony in Massachusetts. ${ }^{44}$

\section{A Lack of Masons}

The near-total absence of masons and bricklayers among the Woodbridge building tradesmen is striking. Even Smith and Dunham were workers in wood. Only John French, the town's bricklayer, practiced a masonry trade. ${ }^{45}$ In any case, to furnish brick on a Woodbridge job site would have meant sourcing the material from outside the township, perhaps from Elizabethtown, Newark, or even New York City, floating it in to the nearest landing. In September 1669 , the town granted French a 10 -acre house lot at a place of his choosing, ${ }^{46}$ and the East Jersey proprietors followed with a patent for that lot in December 1670, but French sold

\footnotetext{
${ }^{42}$ Woodbridge, Liber A, 177.

${ }^{43}$ Ibid.

${ }^{44}$ CNJR, 170-71.

${ }^{45}$ French described himself as a mason; Dally referred to him in one passage as a "dealer in brick" but without revealing his source for that characterization. Joseph W. Dally, Woodbridge and Vicinity: The Story of a New Jersey Township (Orig. published 1873; Reprint, Lambertville, NJ: Hunterdon House, 1989): 20.

${ }^{46}$ Woodbridge, Liber A, 168.
} 
it back immediately to the province's surveyor-general, Robert Vauquellin. French didn't acquire other property, and probably didn't investigate the clay that underlay the topsoil. These circumstances also mean that early Woodbridge houses were very likely to have been "earthfast," that is, with the wood frame in direct contact with the ground, simply because, working alone, French could not possibly have constructed masonry foundations for each one. ${ }^{47}$ A contemporary, writing in the early 1680s, noted that even the chimneys in East Jersey's houses had been and still were of timber and clay, "as the manner of this country is to build." 48 His frame of reference would have been the houses of Elizabethtown (where he at first resided) and Woodbridge (on the road between Elizabethtown and Perth Amboy). Thus it would seem that carpenters were building many of the first chimneys or overseeing their construction. Evidently John French, working alone, was unable to prompt a shift even to brick chimneys in Woodbridge, let alone masonry foundations. He died in Woodbridge in $1713 .{ }^{49}$

\section{Piscataway Township and a Second Wave}

The Township of Piscataway, although it shares the same birth year as Woodbridge, 1666, was slower to develop, slower to attract settling families, and slower to attract building tradesmen. To use the wave analogy, this second wave came later and was longer and shallower than the first. In 1673, when Woodbridge included 64 adult men, Piscataway yet had only $43 .{ }^{50}$ Was there a relationship between the availability of building tradesmen and the ability of a town to attract families to settle there? The evidence from Middlesex County does not support causeand-effect conclusions. Was Piscataway less of a draw for building tradesmen because it was

\footnotetext{
${ }^{47}$ For a discussion of earthfast buildings, see Michael J. Gall, Richard F. Veit, and Robert W. Craig, "Rich Man, Poor Man, Pioneer, Thief: Rethinking Earthfast Architecture in New Jersey," Historical Archaeology, 45, 4 (2011):39-61.

${ }^{48}$ Quoted in Clayton, 603-604.

${ }^{49}$ For French's will, written in 1711/12 and proved in March 1713/14, see Unrecorded Wills, vol.10, fol.41, NJ State Archives.

${ }^{50}$ Pomfret, East New Jersey, 76.
} 
slower to settle? Were families less inclined to settle in Piscataway due to a paucity of tradesmen? James Giles, who settled with his family on the north side of the Raritan River in Piscataway in April 1682, delayed his departure from New York until his new house was ready. ${ }^{51}$ Or was Woodbridge the more attractive of the two because it was nearer to the other East Jersey towns and to New York City?

It has been more difficult to identify the building tradesmen in Piscataway. Of the founding organizers of the town, apparently only one was a carpenter. In July 1668 Hopewell Hull, along with John Martin, Charles Gilman, and Hugh Dunn, entered into an agreement with Daniel Peirce of Woodbridge for a $1 / 3$ division of the land conveyed by Carteret and the Elizabethtown associates to establish the second of the two towns intended for the Raritan River. $^{52}$ Piscataway needed to establish its eastern border with Woodbridge before it could survey and allocate house and meadow lots. Despite a protest by Woodbridge associates over Peirce's agreement, a border dispute with Piscataway was resolved and Piscataway proceeded to lay out town lots.

Still the settling of Piscataway proceeded slowly. ${ }^{53}$ The town apparently reached out to Woodbridge for help. In August 1669 Woodbridge granted the status of freeholder and inhabitant to Thomas Wiatt, an indentured servant, only to reverse itself a month later when the town decided instead that Wiatt would become an inhabitant in Piscataway, "Being one of the four this

\footnotetext{
${ }^{51}$ James Giles' account of his first 14 years in America, 1668-82, survives in various places, including a transcribed copy in the Olden Family Papers, Historical Society of Princeton, Princeton, NJ.

${ }^{52}$ CNJR, 3-4.

53 Michael J. Gall's recent work on Piscataway village supports this conclusion, even though it doesn't explicitly emphasize the comparison. See Michael J. Gall, "The Piscataway Commons: A History of Town Land Use in Piscataway Village," Prepared for the Middlesex County Cultural \& Heritage Commission, September 6, 2009. Gall, an archaeologist, has been studying seventeenth-century Middlesex County from an anthropological viewpoint: see his "An Earthly Tabernacle: English Town Planning in Seventeenth-Century Woodbridge, New Jersey” in Northeast Historical Archaeology, 43 (2014) Article 3.
} 
Towne was to place there." ${ }^{54}$ Woodbridge had apparently committed to help its neighbor by sending four families to augment the small nucleus that Piscataway had already assembled. Identities of the other three families cannot be readily learned from the records, but Piscataway came to be home to several former Newbury families, including those of Richard Dole and Henry Greenland. ${ }^{55}$

In a situation in which the settling families were trying to construct their houses, their barns, and other outbuildings all at once, building tradesmen enjoyed a heightened role in society, and they benefited, taking advantage to create a seller's market for their services. Certainly the indispensability of their work allowed them to demand a premium for their craft skills. Their per diem rates were well above those that prevailed for daily labor, they were among the relatively few who could sell their services by the job rather than by the day or the month, and still they often ran away, leaving jobs unfinished to pursue better opportunities elsewhere. Benjamin Clarke of Piscataway experienced this problem first-hand in 1689 when one tradesmen left him in the middle of plastering his house, and another left him with a henhouse unfinished. ${ }^{56}$

Hopewell Hull seems the likely candidate for leading the construction of Piscataway's meetinghouse. When that building needed finishing in 1689/90, the town asked him to complete the building, ${ }^{57}$ and in 1692 Hull was elected by the town to represent it in the East Jersey

\footnotetext{
${ }^{54}$ Woodbridge, Liber A, 167.

${ }^{55}$ See for example, Elizabeth G.C. Menzies, Millstone Valley, (New Brunswick, NJ: Rutgers University Press, 1969): 37-38, 44-45. Greenland was a controversial figure, both in Massachusetts Bay and in New Jersey. For a biographical profile, see John M. Murrin, “A Very Troublesome Person: Princeton's First Settler, Dr. Henry Greenland," Princeton History, 9 (1990): 1-17. It may not have been a coincidence, then, that although in Massachusetts Bay Greenland had been a Newbury man, in New Jersey he ended up in the remote reaches of Piscataway.

${ }^{56}$ Craig, "Benjamin Clarke, Sr., and His Diary," 393-438.

${ }^{57}$ Clayton, 591.
} 
Assembly. ${ }^{58} \mathrm{He}$ died during the spring of $1693 .{ }^{59}$ Two other carpenters were active in Piscataway at an early date. One named John Wilson died in 1672 or $1673 .{ }^{60}$ He died intestate and letters of administration were granted to Samuel Moore of Woodbridge. Clayton, citing a tradition that was still current in the 19th century, noted that he was called "Great John" by his contemporaries. ${ }^{61}$ John Terry was a carpenter who died in Piscataway in 1678. His presence is known chiefly from the letters of administration of his estate, which were granted to still another carpenter, one with a more lasting presence in Piscataway, Vincent Runyon. ${ }^{62}$

Runyon (the native spelling was probably close to "Rongnon") was the only carpenter of French origin yet identified in early Middlesex County. ${ }^{63}$ Governor Carteret solemnized his marriage in 1668 , an indication that he was already present in the colony. He bought a house lot in Elizabethtown in $1672,{ }^{64}$ but he was in Piscataway by 1678 when he was granted letters of administration for Terry's estate. The fact that carpenters were moving from Elizabethtown suggests that the initial wave of construction in Elizabethtown had slowed as Piscataway was heating up. Runyon sold his house lot and some of his other Piscataway lands in 1680, however, and moved to Staten Island, where in 1686 he was appointed a commissioner of excise. He returned to Piscataway soon thereafter, in $1687 / 8$ buying a 70 -acre property from fellow

\footnotetext{
${ }^{58}$ Ibid., 159.

${ }^{59}$ CNJR, 194, 205.

${ }^{60} \mathrm{Cf}$. CNJR, 034 and Clayton, 590. (This Wilson is not to be confused with a John Wilson who resided in Middletown, Monmouth County.)

${ }^{61}$ Clayton, 590. The nickname served to distinguish him from another John Wilson, a local wheelwright.

${ }^{62}$ CNJR, 42.

${ }^{63}$ According to an online biographical sketch of Runyon, he was born in May 1645 in Poitiers, France, but emigrated to New Jersey perhaps by way of the Isle of Jersey. A marriage license for himself and his wife, one Ann Martha Boucher, was signed by East Jersey governor Philip Carteret in June 1668, indicating Runyon's presence in Elizabethtown by that date. See www.geni.com/people/Vincent-Runyon-Rongnion/6000000006110669683.

${ }^{64}$ Clayton, 24.
} 
carpenter Hull. Runyon remained in Piscataway and survived into the 18th century, witnessing a sale of land to Thomas Grubb, a blacksmith, in $1706 .{ }^{65} \mathrm{He}$ died in 1713.

Eliakim Higgins, a carpenter who resided in Piscataway at least as early as 1683, exemplifies another difficulty in tracing the careers of building tradesmen: they tended to reclassify themselves as yeomen once they acquired enough property to qualify for that social status. ${ }^{66}$ In August 1683, Higgins, as a "carpenter," sold 55 acres at the Dismal Swamp in Piscataway. ${ }^{67}$ Still in Piscataway, he sold 104 more acres in February 1684/5. ${ }^{68}$ Only two months later, however, he had 140 acres in Burlington County surveyed for himself, and a month later he bought 100 more acres there. ${ }^{69}$ This was the last document in which he styled himself "carpenter." In subsequent land transactions he self-identified as a yeoman. Whether he continued to practice carpentry in Burlington County is unclear. It would seem likely that he did, at least on a part-time basis, since it was so lucrative. In 1694/5 Higgins gave a mortgage on 130 acres of his land to Peter Resniere, a Burlington shipbuilder, a suggestion that he came to know and work with other carpenters of his adopted county. ${ }^{70}$ Higgins came back to Woodbridge before he died in $1698 .^{71}$ This pattern in the evidence, of building tradesmen ascending from mechanic to yeoman, characterizes both Woodbridge and Piscataway, and sets them apart from Perth Amboy.

\footnotetext{
${ }^{65}$ Early Middlesex deeds, p.1, Early Middlesex County records collection, Division of Special Collections and University Archives, Rutgers University Libraries, New Brunswick, NJ.

${ }^{66}$ The meaning of "yeoman" in its legal and social contexts under English law is well explained in R.H. Tawney, The Agrarian Problem In the Sixteenth Century (Reprint, New York and London: Harper Torchbooks, 1967): 27-28 et passim.

${ }^{67}$ CNJR, 165.

${ }^{68}$ Ibid., 207.

${ }^{69}$ Ibid., 360, 414.

${ }^{70}$ Ibid., 454.

${ }^{71}$ Ibid., 284.
} 


\section{Perth Amboy and a Third Wave}

The beginning of the construction of Perth Amboy in 1683 marked the start of what might be considered a third construction wave in Middlesex County. From the start, there were two basic types of houses that the East Jersey proprietors sought to build there. Deputy-governor Thomas Rudyard wrote back that he had under construction a number of small, timber-framed houses for workmen. He also began efforts to have twenty-four larger, framed houses built, one for each of the proprietary shares. These became known as the "proprietors' houses."72 They were intended to be frame houses of two stories, not less than 30 feet long, 16 feet deep, and 18 feet high in their posts and studs, below the garret. ${ }^{73}$ They were also expected to have a glass window in each room facing the front. ${ }^{74}$ The proprietors expected to be able to have these houses built for not more than $£ 30$ sterling apiece. ${ }^{75}$ That would translate to a higher figure in the trade barter of the colony, and surveyor general Samuel Groom, writing in the summer of 1683, estimated that the houses under construction would each cost about $£ 50$. Only three houses had then been completed. ${ }^{76}$ One East Jersey proprietor, Thomas Warne, arrived and built one of the houses for himself. A second of the intended twenty-four was built in 1684 for Benjamin Clarke, himself not a proprietor but instead the former underground London printer who had handled much of the publishing load for the Society of Friends. ${ }^{77}$ Another proprietor, David Mudie, had a stone house built for himself in 1685. Several others of the twenty-four were doubtless built, but the project evidently did not come near completion, and the proprietors seem not to have gone public with the shortfall. Still, the beginnings of a town were achieved, and Perth Amboy

\footnotetext{
${ }^{72}$ East Jersey Proprietors minutes, 1:52 et passim.

${ }^{73}$ Ibid., 1:35-37; East Jersey Deeds, Bk. B, p.50.

${ }^{74}$ East Jersey Deeds, Bk. B, p.50.

${ }^{75}$ Pomfret, East New Jersey, 201.

${ }^{76}$ Ibid., 153.

${ }^{77}$ Craig, "Benjamin Clarke, Sr., and His Diary," 393-400.
} 
was soon hosting sessions of the county court. Rudyard's successor in 1684, Gawen Lawrie, added the construction of a still larger house for the deputy-governor: himself.

The early layout of Perth Amboy featured only one principal north/south street: Market Street, along which the proprietors' houses were first built. By 1686, however, Water Street had been added, parallel to Market and nearer the Arthur Kill, and the proprietors required that the houses built along these streets conform to the requirements for the proprietors' houses. They also came to be known as "front houses," the builders of which were required to conform to the "dimensions for front houses." ${ }^{, 78}$ Small parcels sold without frontage on these streets were known as back lots, and the houses there, to be built for mechanics and tradesmen, came with a different set of requirements. On July 8, 1686, the Board of the East Jersey Proprietors "Agreed and ordered that all houses that shall be built upon any back lot for the future shall not be less than twenty-four feet in length and twelve feet stud."79 These requirements would yield smaller houses of one and one-half stories. Although these were minimums, it was not expected that back houses would exceed the size of front houses. Perth Amboy was the only one of the three towns that aimed to enforce social distinctions through building regulations.

But who built these houses? Lawrie wrote in March 1684, not long after his arrival, to the effect that "Fifty Scots and Englishmen were employed building houses and a governor's mansion." working in the colony at the time. While the number of locally-resident building tradesmen could have been temporarily supplemented by men from Woodbridge, Elizabethtown, or Staten Island, reaching the figure of fifty with names that have been identified is impossible. It seems more

\footnotetext{
${ }^{78}$ East Jersey Proprietors minutes, 1:114 et passim. Also referred to as "dimensions for front lots." ${ }^{79}$ Ibid., 1:135.

${ }^{80}$ Pomfret, The Province of East New Jersey, The Rebellious Proprietary (Princeton, NJ: Princeton University Press), 194.
} 
likely that the workforce was composed of several carpenters assisted by a larger number of laborers, just off the boat. If Scots predominated among the building crews, then one might deduce that they were among the recent Scottish arrivals of indentured servants, most of them farm laborers, the only source of so much Scottish labor in the colony.

Some men have been identified who likely helped build Perth Amboy. John Shotwell, a carpenter from Elizabethtown whose family had been banished to Staten Island and their land seized by Governor Carteret in 1672, bought land along the Raritan River in $1681^{81}$ and may have returned to practice his trade two years later after then deputy-Governor Lawrie rescinded Carteret's action. ${ }^{82}$ John Decent, a carpenter, came to Middlesex County from Elizabethtown in 1684, and in addition to his own efforts, he sold to Miles Forster of Perth Amboy a black slave, 'Coffey,' who was, himself, a carpenter. ${ }^{83}$ Thomas Warne, the proprietor, also was a carpenter, and records indicate that he had at least three apprentices to the trade: Anthony Ashmore, John Kaighin (Kaighn), and Walter Newman. ${ }^{84}$ These three men were part of the Scottish migration. ${ }^{85}$

The East Jersey proprietors had concluded that the colony was short of building tradesmen of all kinds. Samuel Groom had commented that "progress was slow because of the scarcity and poor capabilities of the workmen." He also noted that "the best [workmen] were those who could spare time from their farming." $" 86$ This was probably an oblique reference to the building tradesmen of Woodbridge, who either owned property or aspired to. The proprietors realized that specific steps were needed both to raise their numbers and to diversify the trades they represented. They offered incentives to any building tradesman willing to be transported to

\footnotetext{
${ }^{81}$ EJD, Bk. 1 (rear), p.153, NJSA.

82 Clayton, 33.

${ }^{83}$ East Jersey Deeds, A/320, NJ State Archives, Trenton, NJ. Forster was one of the East Jersey proprietors.

${ }^{84}$ CNJR, 166,167.

${ }^{85}$ Ibid., 62. The "Kigbin" in this entry is certainly a misspelling of Kaighn. "Scottish" is perhaps misleading with respect to the building tradesmen who arrived in the colony from Britain in the 1680s; many of them are believed to have been recruited from the ranks of the London building trades.

${ }^{86}$ East Jersey Proprietors minutes, 1:153.
} 
the colony: 30 acres of land for himself ("headland") and the promise of a year's employment. ${ }^{87}$ The latter was probably a hollow promise, since the terms of such employment were never spelled out, and since building tradesmen were able to command a premium for their services in the colony, and probably even more in New York City or Philadelphia. ${ }^{88}$ One circumstance that perhaps owed little to the East Jersey proprietors was the growing number of sawmills. In a map drawn by John Reid about 1685, five sawmills are shown in the province, at least two of which were newly constructed in or near Middlesex County. The carpenters who built Perth Amboy probably took full advantage, and it may be that all of the boards they used were mill-sawn, not hand-sawn or split and hand-planed, as some of the boards in the earliest Woodbridge and Piscataway houses probably were. This would not only have sped up construction, it would have made housebuilding slightly less expensive. ${ }^{89}$

Of the nearly 150 men $^{90}$ that the proprietors successfully recruited to come to East Jersey, at least seventeen--more than 10 percent--were building tradesmen who were put to work in Perth Amboy. These included five carpenters: William Frost, John Geddes, Henry Page, John Tankin, and William Thompson; a joiner: Henry Gray; three blacksmiths: Ralph Grant, Thomas Grubb, and John Stephens; three masons: John Cockburn, John Hume, and James Murray; and two bricklayers: Thomas Gibbs and Robert Ham. William Strayherne was a house painter, and James Bland was a "glasier," or window maker, both of them the first of their trades yet identified in the colony. The fact that a glazier was recruited is evidence that the proprietors wanted a better class of windows, at least in the homes built for themselves. Thomas Parr, who

\footnotetext{
${ }^{87}$ Clayton, 422.

${ }^{88}$ See, for example, Gabriel Thomas' claim of the compensation rates for building tradesmen, in his 1698 account of Pennsylvania and West New Jersey. Albert Cook Myers, Narratives of Early Pennsylvania, West New Jersey, and Delaware, 1630-1707 (New York: Charles Scribner's Sons, 1912): 326.

${ }^{89}$ See the Reid map of East New Jersey, ca.1685, Records of the East New Jersey Proprietors, NJSA.

${ }^{90}$ Ned Landsman placed the documented figure at 149. See Ned Carl Landsman, "Scottish Communities in the Old and New Worlds, 1680-1760," Ph.D. dissertation, University of Pennsylvania, 1979, 191.
} 
arrived in 1684, was the first brick maker in the province. This last is perhaps the most striking. Woodbridge and Perth Amboy are situated at the heart of what in the 19th century became known as the Middlesex County clay district, one of the most important places in the United States for the making of brick, fire brick, architectural terra cotta, and other clay products, yet for an entire generation, this wealth in the ground went completely unexploited.

What these men share in common is that we know very little about them. Perth Amboy had trouble holding onto its building tradesmen, just as other places did. Some of them may have succumbed to the mortality that stalked the colony. Not all of them were equally skilled or equally trustworthy. ${ }^{91}$ Each man arrived to serve for four years as an indentured servant, and few of them remained at Perth Amboy after their "time was out" (to use the expression that they used). Most of them apparently sold their headland rights and moved on. Cockburn and Strayherne went to Elizabethtown after they completed their time; Thomas Grubb moved on to Piscataway by 1690 , and John Geddes took jobs there. Few ever became leaders in the Perth Amboy community.

Only three men from this group, all carpenters, made their careers in Perth Amboy. William Thompson arrived in December 1685 as a servant to Lord Neil Campbell, the soon-tobe successor to deputy-Governor Lawrie. He acquired two small lots in Perth Amboy after his time was out and remained there until he died in 1698. John Tankin arrived in June 1685 as a servant recruited by future governor Andrew Hamilton. When his time was out, instead of selling his headland rights and moving on as others did, he accepted a patent for a lot in Perth Amboy. ${ }^{92}$ He apparently spent the remainder of his life in the town, and died about 1700. William Frost was the one man among the seventeen who made the most significant impact on

\footnotetext{
${ }^{91}$ East Jersey Proprietors minutes, 1:33.
}

92 CNJR, 117. 
the town. "Imported" by the proprietor William Dockwra, Frost arrived at Perth Amboy in October 1684, so that his time would have been out in October 1688, at which time he accepted a patent for his headlands, about 100 acres, and remained in Perth Amboy. A few years later he sold his headlands, which were surveyed in Piscataway, and bought additional lots in Perth Amboy. Perth Amboy received a municipal charter in 1718, and in the petition for that charter, Frost was joined by three of the longest-active building tradesmen in the town: carpenters John Sharp and Henry Berry, and bricklayer William Hodgson. Clayton described these and the other petitioners as "men prominent in the affairs of the town and province at that period." 93 Further research may reveal whether these men were involved in the building of the first Middlesex County Court House in 1713. They are also likely to have been involved in the building of the first St. Peter's Anglican Church, begun in 1719 and dedicated in 1722. Frost left a legacy of property to the church when he died in 1725, after a Perth Amboy career spanning forty-one years.

Perth Amboy has justifiably earned a reputation as a place apart from the rest of eastern New Jersey: more beholden to the proprietors, more Anglican in religious matters, more Loyalist during the American Revolution, and more adversely affected and more diminished by the war and its aftermath. All of these differences trace back to the beginnings of the town, and they have their physical reflection in the town's first construction, and the identities and conditions of servitude of its first building tradesmen.

\section{Conclusion}

Middlesex continued to grow after the third wave. The 1680 s and '90s witnessed the emergence of a new generation of building tradesmen in each town, men who evidently learned their trade skills in New Jersey. In Woodbridge, for example, these included Ezekiel Bloomfield

\footnotetext{
${ }^{93}$ Clayton, 608.
} 
and his contemporaries; in Piscataway, the FitzRandolphs, Benjamin and John; and in Perth Amboy the aforementioned Sharp, Hodgson, and others. The eighteenth century witnessed the rise of the townships south of the Raritan River, yet that story, too, has its beginnings before the end of the proprietary era. Settlement began on the south side of the river where some building tradesmen were active before 1700, including John FitzRandolph of Piscataway, who moved to the Millstone River in the 1690s, near what would later become Princeton, and Anthony Ashmore, who turned up at Cranbury Brook by 1698 as the first carpenter identified there. The flowering of these areas into townships, however, would wait until the second quarter of the eighteenth century, and still another--and much larger--generation of building tradesmen.

From available evidence, one might reasonably conclude that it is possible to write a history of colonial New Jersey from the point-of-view of the men who actually constructed the colony. Such an account by its nature would be a social history, examining New Jersey developmentally from its birth under Carteret through its toddlerhood as a divided and fragmented proprietorship. As the latter years of the seventeenth century played out, the proprietary governments collapsed under the weight of their own internal contradictions. Compared to their failure, the work of this era of building tradesmen made New Jersey a permanent place and erected a sturdy foundation on which to keep building the eighteenth century colony. Evidence also suggests that similar studies could be made of farmers and husbandmen, and of weavers and other textile producers, that would provoke new explanations of how the colony was fed and clothed, not only how it was housed. Looking at New Jersey in this way touches on the traditional, political narrative, but such an approach really yields a different, parallel story. It does, however, promise a flexible framework on which to interweave 
the economic, social, religious, intellectual, and even political, evolution of New Jersey, for a fuller, more well-rounded understanding that would better serve the 99 percent.

Robert W. Craig is a historian and architectural historian who has been active in New Jersey for more than four decades. He holds an M.S. degree in Historic Preservation from Columbia University and a B.A. degree in History from Syracuse University. He is the author of The Princeton Architectural Survey (1981), the report of the New Jersey Black Historic Places Survey (1984), and a study of the Delaware Valley's octagon schoolhouses (1988). He was a contributor to both the Encyclopedia of New Jersey and Mapping New Jersey. He edited Down Jersey: From Bayshore to Seashore (2014). His subjects have included cartographic history, early American transportation history, and the historic preservation movement, and his work has appeared in several journals, including Historical Archaeology, New Jersey History, The Portolan, and the Princeton University Library Chronicle. He specializes in the development of archival research methods for the study of historic buildings. In 2003 he was elected a member of the Princeton Research Forum, an organization of independent scholars. 